\title{
OVER HET MARGINALISEREN VAN VERANDERINGSPROCESSEN IN DE INTERNE ORGANISATIE VAN ONDERNEMINGEN
}

\author{
door Drs. J. G. L. M. Willems
}

\section{Inleiding}

In toenemende mate treft men in de organisatietheorie de gedachte aan, dat de organisatie van ondernemingen gebaat is bij flexibiliteit. Het organiseren is in deze opvatting niet langer vooral of uitsluitend gericht op het creëren van samenwerkingsverbanden die efficiente afhandeling van lopende produktieprocessen mogelijk moet maken, doch moet mede gericht zijn op het tot stand brengen van organisaties die over een zekere mate van aanpassingsvermogen beschikken. ${ }^{1}$ ) De instrumentele organisatietheorie richt zich daarom tegenwoordig in belangrijke mate op de vraag op welke wijze de flexibiliteit van organisaties kan worden verkregen. Zo is onder meer door Ansoff en Brandenburg ${ }^{2}$ ) ingegaan op de vraag welke de relatie is tussen bepaalde organieke structuurmodellen (het functionele, het divisionele, het adaptieve, en het innovatieve) enerzijds, en bepaalde vormen van flexibiliteit (operational responsiveness, strategic responsiveness, en structural responsiveness) anderzijds.

Ook in dit opstel wordt aangesloten bij de gedachte, dat in deze tijd voor tal van ondernemingen de flexibiliteit een kwaliteitsaspect van betekenis is geworden. Uitgangspunt voor het voorliggende opstel is de gedachte, dat de flexibiliteit van de organisatie in het algemeen ernstig kan worden aangetast door het bestaan van menselijke weerstanden tegen veranderingen. Bestaan immers dergelijke weerstanden, dan kunnen die er toe leiden, dat veranderingen in de organisatie van de onderneming veelal slechts met moeite kunnen worden doorgevoerd, zodat minstens de - wat Malotaux heeft genoemd $^{3}$ ) - ,reactiesnelheid" wordt aangetast. Weerstanden kunnen bovendien een zodanige vorm aannemen, dat voorgenomen veranderingen de facto in het geheel niet blijken te kunnen worden geïmplementeerd. In extreme gevallen zijn zelfs wilde stakingen er het gevolg van geweest. ${ }^{4}$ )

Tegen de achtergrond van het streven naar flexibele organisaties zal nu in dit opstel worden ingegaan op het verschijnsel van de menselijke weerstand tegen verandering. Daarbij staat centraal een poging tot het formuleren van aanbevelingen welke de weerstand tegen verandering zouden kunnen minimaliseren. In aansluiting bij de zienswijze van $\operatorname{Argyris}^{5}$ ), welke inhoudt, dat een onderscheid moet worden gemaakt tussen fenotypische en genotypische veranderingen - wij komen hierop later nog terug - zou men dit ook zo kunnen formuleren, dat in de instrumentele organisatietheorie getracht zal worden,

1) Zie onder meer Van der Schroeff (1968), blz. 299-300; vgl, ook Wattel (1968), blz. 485-486; vgl. ook Blake en Mouton (1968) en (1969). Zie echter vooral Ansoff en Brandenburg (1969). In de laatstbedoelde publicatie wordt het flexibiliteitsbegrip verder uitgewerkt dan men in de literatuur veelal aantreft.

2) vgl. Ansoff en Brandenburg (1969).

3) vgl. Malotaux (1966).

4) vgl. Gouldner (1955).

5) vgl. Argyris (1964), blz. 11 e.v. 
op basis van de onderkenning van bepaalde causale relaties, te komen tot het geven aan aanbevelingen die de veranderingsprocessen in de organisatie zoveel mogelijk „marginaliseren". Wij hebben aan de laatste wijze van formulering de voorkeur gegeven, omdat die korter is, en wellicht minder geladen dan die waarin gesproken wordt van het ,minimaliseren van weerstanden tegen veranderingen". Bovendien menen wij dat in de door ons gekozen formulering beter tot uitdrukking komt, dat - zoals later nog zal blijken - de eigen inhoud van de verandering niet als als een constante behoeft te worden gedacht, doch juist mee gevarieerd kan worden binnen het kader van het marginaliseren van veranderingsprocessen.

In dit opstel zal allereerst worden nagegaan op welke wijze het verschijnsel van de menselijke weerstand tegen verandering kan worden verklaard. Daarna $\mathrm{zal}$ meer in het bijzonder worden nagegaan welke factoren de feitelijke mate van weerstand bepalen, zoals die van geval tot geval kan verschillen. Vervolgens willen wij trachten een samenvattend overzicht te geven van enige van de belangrijkste factoren die door de leiding van de onderneming te beïnvloeden zijn binnen haar streven naar marginalisering van veranderingsprocessen, gericht als deze zijn op de flexibilisering van de organisatie. Daarna zal worden getracht enige algemene aanbevelingen te formuleren terzake van het hier te voeren beleid. Tenslotte wordt enige aandacht gegeven aan het verschijnsel dat de afgeleide aanbevelingen niet slechts normatief kunnen worden gefundeerd, doch eveneens het resultaat kunnen zijn van een strikt instrumentele analyse.

\section{Aanpassingsvermogen en weerstand tegen verandering; universele verschijnselen}

Waar in dit opstel het verschijnsel van de menselijke weerstand tegen verandering een zo belangrijke plaats inneemt, is het dienstig dit op voorhand enigermate te relativeren. Zonder dat te doen, zou licht de indruk kunnen ontstaan, dat aan het verschijnsel mens iedere vorm van aanpassingsvermogen vreemd zou zijn. Dit laatste is bepaaldelijk niet het geval. In vergelijking tot het dier heeft juist de mens een relatief grote mate van aanpassingsvermogen. De denkende mens heeft zijn gedrag in belangrijke mate aangeleerd; zijn daden komen niet - zoals bij het dier het geval is - primair voort uit de werking van erfelijk gegeven mechanismen, doch komen veeleer tot stand uit een - zij het soms primitieve vorm van - overleg. ${ }^{6}$ ) Tussen mens en dier is wat dit betreft, in de woorden van Bergson ${ }^{7}$ ), niet een ,différence de degré", maar een ,différence de nature".

Indien nu het menselijk gedrag overwegend is aangeleerd, dan kan het ook - zo wordt het menselijk aanpassingsvermogen wel verklaard - opnieuw, en wel ànders worden aangeleerd, worden verleerd en herleerd, zodra de omstandigheden daartoe nopen. Op deze wijze wordt het aanpassingsvermogen van de mens verklaard uit het specifiek menselijke van de menselijke natuur. ${ }^{8}$ ) Even universeel als het menselijk aanpassingsvermogen blijkt even-

6) vgl. Van Peursen (1970), blz. 128 e.v.

7) vgl. Bergson (1962), blz. 183.

8) Zie bv. Fromm (1971), vgl. eveneens Oldendorff en Daniels (1965). 
wel het verschijnsel van de menselijke weerstand tegen verandering te zijn, dat eveneens uit het specifiek menselijke van de menselijke natuur verklaard wordt. Dezelfde ,,instinctarmheid” - zo luidt de redenering, die wij hier slechts zeer in het kort kunnen weergeven -, die de mens vrij maakt van erfelijke conditionering, doet tegelijkertijd een gebrek ontstaan aan natuurlijke of instinctieve zekerheid. ${ }^{9}$ ) Het behoort tot het wezen van de mens, dat hij aarzelt, en geconfronteerd wordt met het problematisch karakter van zijn bestemming. ${ }^{10}$ ) Men treft de natuurlijke zekerheid, die bij uitstek kenmerkend schijnt te zijn voor het handelen der dieren, bij deze instinct-arme mens niet aan. $\mathrm{Nu}$ wordt aangenomen, dat, door het crëeren van gewoonten en tradities, de mens tracht zichzelf een zekere ,substituut-vanzelfsprekendheid" te verschaffen, welke hij in de evolutie heeft verloren, doch waaraan hij nochtans behoefte heeft gehouden. ${ }^{1}$ ) De mens bootst het instinctmatig „weten”, en het instinctmatig handelen der dieren na, door zijn gedrag te conformeren aan nieuwe gewoonten en gedragspatronen, die niet door de natuur worden gedicteerd, maar door hemzelf aan hemzelf zijn opgelegd. Hij verschaft zich daarmee - moeizaam - een zeker gevoel van zekerheid, tegen ondergraving waarvan hij zich in het algemeen zal verzetten. Johnson, Kast en Rozenzweig ${ }^{12}$ ) formuleren dan ook treffend: „We tend to resist changes in our interpersonal and job relations because our sense of security and the way we have been accustomed to do things are threatened".

\section{Enige factoren die de feitelijke mate van weerstand tegen verandering bepalen}

De opvatting dat de mens in het algemeen een zekere weerstand tegen verandering zal voelen, terwijl hij toch tegelijkertijd over aanpassingsvermogen beschikt, is zojuist in algemene zin besproken. In het kader van de problematiek van het op marginalisering van veranderingsprocessen gerichte beleid, zal nu de aandacht moeten worden gericht op de vraag welke factoren de feitelijke mate van weerstand in een bepaald geval zullen bepalen. Hierbij moet in de eerste plaats worden gewezen op de invloed van de persoonlijkheidsstructuur. Volgens Barnes ${ }^{13}$ ) is in dit verband van belang te onderscheiden in „radicals", „rational resisters", „rational advocates" en ,traditionalists”. Radicals en rational advocates vertonen volgens Barnes een neiging tot het verwelkomen van veranderingen, $\mathrm{zij}$ het in verschillende mate en op verschillende gronden. Rational resisters en traditionalists verzetten zich vanuit hun persoonlijkheidsstructuur tegen veranderingen; zij het wederom, met verschillende intensiteit, en ook op verschillende gronden. Wat dit laatste betreft merkt Barnes op, dat de rational resisters die mensen zijn, die zich tegen veranderingen zullen verzetten, indien hen niet duidelijk is geworden, dat de verandering ook inderdaad een verbetering van de situatie zal betekenen. Of zij hierbij onder ,situatie” zullen verstaan hun eigen situatie, de situatie van

9) vgl. Fromm (1971), blz. 25-59.

10) vgl. bv. Krüger (1962), blz. 13-23.

11) vgl. Van den Berg (1965), blz. 58. Zie ook blz. 173-174.

12 ) Johnson, Kast en Rozenzweig (1967), blz. 373.

13) Barnes (1968), blz. 61-62.

$m a b$ blz. 210 
hun afdeling, dan wel de situatie van de onderneming als geheel, zal daarbij afhangen van hun loyaliteit ten opzichte van de onderneming als geheel, en van de mate waarin zij zich ,,provincialistisch" opstellen. ${ }^{14}$ )

In de typologie van Barnes zijn de rational resisters die mensen die steeds de reële of intrinsieke verdienste van een verandering trachten te analyseren, en de verandering dan afwijzen indien zij die verdienste niet, of in te geringe mate, kunnen ontdekken. Traditionalists bekommeren zich over de intrinsieke inhoud minder sterk. $\mathrm{Zij}$ stellen zich volgens Barnes tegen veranderingen vijandig op: „for less objective reasons". ${ }^{\text {5 }}$ ) Volgens Barnes moet derhalve worden beklemtoond, dat de feitelijke mate van weerstand tegen verandering, alsmede het subjectieve, dan wel objectieve karakter daarvan, in belangrijke mate bepaald wordt door de persoonlijkheidsstructuur van de betrokkenen. Hiermee is derhalve aan het verschijnsel van de ,universele weerstand" reeds een dimensie toegevoegd. Voor het doel van dit opstel moet intussen wel worden bedacht, dat de persoonlijkheidsstructuur van de betrokken mensen, door de leiding van de onderneming praktisch gesproken - en ook moreel gesproken - als een onbeïnvloedbare factor kan worden beschouwd. Hoogstens zou de leiding in het kader van de personeelsselectie kunnen trachten zoveel mogelijk „rationalists” aan te trekken. Daarbuiten evenwel moet de persoonlijkheidsstructuur worden beschouwd als een factor die weliswaar op de feitelijke mate van weerstand tegen verandering wel van invloed is, doch die als zodanig door de leiding niet is te manipuleren.

In het kader van dit opstel zal op andere - wel te manipuleren variabelen de klemtoon moeten worden gelegd. Zonder op dit moment nog een onderscheid te maken naar de mate waarin ze kunnen worden beïnvloed, en de termijn waarop ze kunnen worden beïnvloed, willen wij als zodanig noemen:

- de eigen inhoud van de verandering;

- de persoonlijke omstandigheden van de betrokkenen;

- de wijze van voorbereiding en introduktie van de verandering;

- het vertrouwen in de veranderaar;

- de duur van de aan de verandering voorafgaande veranderingsloze periode; en

- de aantoonbaarheid van de verbetering.

Wij zullen in het navolgende hierop nader ingaan. Daarbij zij opgemerkt, dat binnen de ruimte van dit opstel een tweetal beperkingen noodzakelijk zijn. In de eerste plaats beperken wij ons met het bespreken van de genoemde factoren tot enige van de belangrijkste. Bovendien zal de bespreking per factor noodzakelijkerwijs beknopt dienen te zijn.

\section{De eigen inhoud van de verandering}

Nadat in het voorgaande werd gewezen op de omstandigheid, dat de feitelijke mate van weerstand tegen verandering mede afhankelijk is van de eigen aard van de betrokken mensen, moet thans worden gewezen op de invloed die te dezen uitgaat van de eigen aard van de verandering. Wij sluiten hiermee 14) vgl. voor dit begrip o.m. ook Hardwick en Landuyt (1966).

15) vgl. Barnes (1968), blz. 67.

$m a b$ blz. 211 
aan bij inzichten die in de organisatietheorie onder meer door Argyris en Coltof naar voren zijn gebracht. Volgens Coltof is ,,verandering als zodanig" een te algemeen begrip, en moet voor de analyse vaak een onderscheid worden gemaakt naar de eigen aard van veranderingen. Coltof onderscheidt hierbij veranderingen van het eerste, veranderingen van het tweede en veranderingen van het derde niveau, welke hij alsvolgt omschrijft: ${ }^{16}$ )

- veranderingen van het eerste niveau betreffen inhoudelijk niet meer dan reorganisatie van organisatorische processen;

- veranderingen van het tweede niveau zijn die welke aanpassing nodig maken terzake van de constellatie van de door de mensen in de organisatie ingenomen rollen, en die als zodanig door de betrokkenen worden onderkend;

- veranderingen van het derde niveau zijn die veranderingen die vragen om aanpassing van het gedrag van de betrokken mensen; van houdingen, eigenschappen en waardeoordelen.

De bovengenoemde indeling in soorten veranderingen, welke een indeling is naar verschillen in - wat Coltof noemt - ,penetratiediepte", bedoelt te onderstrepen, dat - ceteris paribus - een grotere weerstand tegen veranderingen mag worden verwacht, naarmate de penetratiediepte van de verandering groter is. ${ }^{17}$ ) Op soortgelijke wijze zou men, in aansluiting bij de terminologie van Argyris, die door hem weer is ontleend an het terrein van de klinische psychiatrie, de veranderingen kunnen indelen in marginale, fenotypische en genotypische. ${ }^{18}$ ) In de genoemde volgorde is ook hier de penetratiediepte van de verandering steeds groter. Wij zullen later nagaan in hoeverre de leiding van de onderneming vrijheid heeft de eigen inhoud van de verandering - bij min of meer gelijkblijvende ,problem-solving-capacity" daarvan - te beïnvloeden. Voorlopig richten wij de aandacht op de verdere bespreking van de in paragraaf 3 genoemde factoren die van invloed zijn op de feitelijke mate van weerstand tegen verandering.

\section{Persoonlijke omstandigheden van de betrokkenen}

Op de feitelijke mate van weerstand tegen verandering, persoonlijkheidsstructuur van betrokkenen en de eigen inhoud van de verandering constant gedacht, blijken tal van persoonlijke omstandigheden van betrokkenen van invloed te zijn. Zo is vastgesteld, dat de weerstand tegen verandering in het algemeen geringer zal zijn, naarmate de betrokkenen maatschappelijk en economisch een grotere mate van zekerheid genieten. Tevens is het toekomstbeeld, als het ware de ,,zekerheidsverwachting", van de betrokkenen een factor die op de feitelijke mate van weerstand van invloed blijkt te zijn. Onder meer door Touraine ${ }^{19}$ ) is hierop gewezen: „Change is more readily accepted by those who already enjoy economic security and have some realistic expectations of achieving further aspirations... those with little

16) vgl. Coltof (1965), blz. 28-30.

17) vgl. Argyris (1964).

18) Argyris (1964), blz. 11.

19) Touraine (1965) (b), blz. 85.

$m a b$ blz. 212 
money and humble expectations are neither secure enough to seek change, nor ambitious enough to welcome it."

Volgens Touraine is vastgesteld, dat te dezen ook factoren als: opleidingsniveau, vermogensbezit, leeftijd, sexe en gezinsomvang een rol spelen. ${ }^{20}$ ) Sociologisch beschouwd is vooral interessant, dat de mate van weerstand tegen verandering de neiging heeft toe te nemen - wederom ceteris paribus -, naarmate de betrokken werknemers in een situatie verkeren waarin minder duidelijk een scheiding bestaat tussen ,het leven op het werk" en ,het leven buiten het werk". Touraine formuleert dit als volgt: „The most significant fact to come out of many studies of this subject is that the more the worker's working life is merged with his life in a community, the more difficult it is to gain acceptance of technical change"2 1 ).

\section{Voorbereiding en introduktie}

Ook in de wijze waarop de veranderingsprocessen in de organisatie worden voorbereid, en bij de betrokkenen worden geïntroduceerd, wordt in het algemeen een factor gezien die de feitelijke mate van weerstand tegen verandering in belangrijke mate mede bepaalt. In het algemeen worden te dezen een drietal verschillende benaderingen onderscheiden ${ }^{2}{ }^{2}$ ), te weten:

a. Introduktie zonder waarschuwing;

b. Introduktie na informatie; en

c. Introduktie na participatie in de besluitvorming.

\section{ad a. Introduktie zonder waarschuwing}

Onder meer door Willener ${ }^{23}$ ) wordt erop gewezen, dat introduktie zonder waarschuwing, dus zonder dat de betrokkenen er op enigerlei wijze op zijn voorbereid, zelfs bij naar hun eigen aard betrekkelijk weinig ingrijpende veranderingen, tot grote weerstanden kan leiden. Coch en French ${ }^{24}$ ) wijzen hierop eveneens nadrukkelijk. Waar de hier bedoelde methode van introduktie in de praktijk veelal kan worden aangetroffen bij - wat men wel noemt - ,krachtige”, of ,strenge" leiders, is het goed erop te wijzen, dat veelal de weerstand, die door deze wijze van introduktie wordt opgeroepen niet openlijk zal zijn, doch een verborgen vorm zal aannemen. Op zichzelf behoeft het effect daarvan evenwel niet minder te zijn dan van openlijke weerstand. ${ }^{25}$ )

\section{ad $b$. Introduktie na informatie}

Introduktie van veranderingen, na de betrokkenen daaromtrent ge ïnformeerd te hebben, heeft in het algemeen het voordeel, dat de betrokkenen mee kunnen groeien in de verandering. „The method of introducing change

20) Touraine (1965) (b), blz. 75-96.

21) Touraine (1965) (b), blz. 76.

22) vgl. bv. Seiler (1970), zie ook Willener (1965).

$23)$ Willener (1965), blz. 61.

24) Coch en French (1948).

25) vgl. Willener (1965), blz. 62. Zie voor een beschrijving van verschillende vormen van verborgen weerstand vooral ook Tannenbaum, Weschler en Massarik (1961). 
should allow the individual to „,build his security”. This process is facilitated by preliminary information", aldus Willener ${ }^{26}$ ).

Te onzent is onder meer door Verburg gewezen op de - wat wij hier noemen - ,veranderings-marginaliserende" werking die van het informeren uitgaat. Verburg geeft daarbij met betrekking tot de wijze van informeren een aantal algemene aanbevelingen ${ }^{2} 7$ ):

- er moet voldoende inzicht worden verschaft omtrent de motieven die tot de voorgenomen verandering hebben geleid;

- de informatie moet niet in vage of vaktechnische termen worden uitgedrukt;

- de informant moet zich verplaatsen in de situatie van de betrokkenen; en

- de motieven voor de verandering moeten zodanig worden geformuleerd, dat de betrokkenen er niet in de eerste plaats een kritiek op zichzelf in kunnen zien.

\section{ad c. Introduktie na participatie}

Meer nog dan bij introduktie na informatie het geval is, is volgens de gangbare opvattingen de participatie in de besluitvorming een doelmatig instrument voor het voorkomen van weerstanden tegen veranderingen, dan wel ter minimalisering daarvan. „People support what they help create”, zo geeft Beckhard ${ }^{28}$ ) de veronderstelling weer, waarop de hier bedoelde methode is gefundeerd. De leider, de veranderaar, of de externe adviseur „dwingen” in deze benadering niet zozeer, maar overtuigen veeleer en bespreken de verschillende oplossingsmogelijkheden van problemen met de betrokkenen, om tezamen tot de formulering van de gewenste maatregelen te komen. De hier bedoelde benadering, die in wezen aansluit bij Drucker's conceptie van het „management by objectives"29), bij McGregor's aanbevelingen inzake "Management by integration and selfcontrol"3 0 ), en bij Likert's "Participative management" ${ }^{11}$ ) vindt men ook in de praktijk van het Nederlandse advieswerk terug. Bosboom ${ }^{32}$ ) wijst hierop, waar hij aangeeft, dat de organisatieadviseur zich steeds minder gaat beperken tot het geven van afgeronde adviezen, maar zich in toenemende mate ook richt op het proces van bewustwording in de organisatie. Rubinstein ${ }^{33}$ ) wijst op de hier bedoelde ontwikkeling, door aan te geven, dat de oude adviseur vooral opereerde vanuit het inhoudelijke, terwijl in de nieuwe benaderingswijze de adviseur veel meer het proces van verandering als invalshoek kiest, en de participatie in de besluitvorming daarbij allengs als noodzakelijke factor onderkent. ${ }^{34}$ ).

\footnotetext{
26) Willener (1965), blz. 62.

$27)$ Verburg (1966), blz. 184.

28) Beckhard (1969), blz. 27.

29) vgl. Drucker (1954).

30) vgl. McGregor (1960). Opgemerkt zij, dat McGregors benadering weer in belangrijke mate steunt op Drucker's conceptie van Management by Objectives, vgl. hiervoor verder Willems (1974).

31) vgl. Likert (1967).

32 ) vgl. Bosboom (1964).

33) Rubinstein (1971), blz. 209.

34) zie bv. ook Kuyken (1966).
} 


\section{Het vertrouwen in de veranderaar}

In de onderhavige bespreking van factoren die van invloed zijn op de mate van weerstand die tegen veranderingen zal ontstaan, mag de factor van het vertrouwen in de veranderaar niet onbesproken blijven. De leiding - of meer in het algemeen de veranderaar - die over het vertrouwen van de bij de verandering betrokkenen beschikt, heeft daarmee de beschikking over een niet onbelangrijk veranderings-marginaliserend instrument. Voor zover ons bekend is het vooral Judson ${ }^{35}$ ), die deze factor systematisch in zijn beschouwing over het verloop van veranderingsprocessen betrekt. Zoals onder meer door Newman, Summer en Warren ${ }^{36}$ ) wordt onderstreept, gaat het hier niet slechts om het vertrouwen in de formele leiding. De bereidheid veranderingen te accepteren zal mede afhangen van het vertrouwen dat de betrokkenen hebben in de informele leiders, zoals die spontaan in de werkverbanden naar voren zijn gekomen. Indien laatstbedoelden de veranderingen accepteren, zal de bereidheid der overige betrokkenen - gegeven vertrouwen in de informele leiding - de veranderingen te accepteren, sterk kunnen toenemen.

Omdat, naar wij menen, de marginaliserende werking van de vertrouwensfactor, op zich weinig nadere toelich ting behoeft ${ }^{\mathbf{3}}{ }^{7}$ ), zij op deze plaats in ons betoog volstaan met het onderstrepen van de labiliteit die in principe iedere vertrouwensrelatie kenmerkt. Is een dergelijke relatie eenmaal bereikt, dan zal de leiding haar met bijzondere aandacht steeds moeten koesteren, opdat zij niet weer verloren zal gaan. Zoals ook met gezagsrelaties het geval is, dragen vertrouwensrelaties steeds de kans op ontbinding in zich, hetgeen niet in de laatste plaats wordt veroorzaakt door de omstandigheid dat - zoals Idenburg schrijft ${ }^{\mathbf{3}}$ ) - ,,ook de meest welwillende en open leiding nu eenmaal staat in een lange traditie van wantrouwen van de werknemer ten opzichte van de werkgever."

\section{De duur van de aan de verandering voorafgaande veranderingsloze periode}

Het is een bekend verschijnsel, dat in organisaties, waarin gedurende langere tijd niets is veranderd, de verhoudingen zozeer kunnen vastroesten en verstarren, dat verandering daarvan bijzonder moeilijk wordt. Gewoontevorming heeft in die omstandigheden zo lang ongebreidelde kansen gekregen, dat een moeizaam proces van - wat men in de Lewiniaanse terminologie zou noemen ${ }^{39}$ ) - ,ontdooiing” nodig zal blijken, om veranderingen te kunnen doorvoeren. Onderkenning van de invloed van de hier bedoelde factor als een factor van invloed op de feitelijke mate van weerstand tegen verandering kan op tal van plaatsen in de literatuur worden aangetroffen. Touraine ${ }^{40}$ ) vermeldt uitdrukkelijk als resultaat van empirisch onderzoek, dat in het algemeen veranderingen gemakkelijker geaccepteerd worden door mensen die

35) vgl. Judson (1966), blz. 36-38.

36) vgl. Newman, Summer en Warren (1972).

37) Zie hiervoor verder bv. Dean (1940), Bennis (1966), Lippitt c.s. (1958), en Davey (1971).

38) Idenburg (1966), blz. 116.

39) Lewin (1947).

40) Touraine (1965) (b), blz. 84.

ma $b$ blz. 215 
aan veranderingen gewend zijn, dan door mensen die zeer weinig frequent met veranderingen in hun werksituatie in aanraking zijn gekomen.

\section{De aantoonbaarheid van de verbetering}

Vooral de categorie van de „rational resisters" zullen zich minder sterk tegen veranderingen verzetten, naarmate zij duidelijker kunnen inzien, dat de verandering ook inderdaad als een verbetering van de situatie kan worden beschouwd. Betrokkenen die weinig loyaliteit gevoelen met de onderneming als geheel, en zich daarmee maar moeilijk kunnen identificeren, zullen zich de vraag stellen of de verandering een verbetering betekent voor de eigen afdeling, of - bij een nog sterkere mate van organisatorisch provincialisme - zelfs alleen naar hun persoonlijke situatie zien. Vooral indien de organisatie wordt gekenmerkt door dergelijke provincialistische trekken, kan het bijzonder moeilijk zijn de betrokkenen duidelijk te maken, dat een bepaalde verandering wenselijk is, omdat zij de totale situatie, dus: die van de onderneming als geheel, zal verbeteren.

Ook echter andere factoren leiden ertoe, dat het veelal bijzonder moeilijk is, aan te tonen, dat de verandering waar het om gaat ook werkelijk een verbetering betekent. Dit hangt samen met de betrekkelijk grote mate van subjectiviteit die bij het organiseren een rol speelt. Onder meer door Acker ${ }^{41}$ ), $\mathrm{Kosiol}^{42}$ ) en vooral ook door $\mathrm{Dale}^{43}$ ) is erop gewezen, dat de instrumentele organisatietheorie op tal van punten nog slechts in uiterst geringe mate kan stoelen op een objectief inzich $t$ in feitelijke causale relaties binnen de organisatie. De voorspellende waarde van de instrumentele organisatietheorie is daardoor - onder meer volgens Dale ${ }^{4}$ ) - veelal nog betrekkelijk gering. Het valt nu gemakkelijk in te zien, dat als gevolg van het veelal overheersende subjectieve element in het organiseren en reorganiseren, de objectieve bewijsbaarheid (ex ante) van de wenselijkheid van bepaalde maatregelen en veranderingen, veelal betrekkelijk gering zal zijn. Daardoor is de rationele weerstand tegen verandering vaak niet eenvoudig te overwinnen, zelfs niet indien de betrokkenen best bereid zijn zich niet-provincialistisch op te stellen.

10 Marginalisering van veranderingsprocessen; de beïnvloedbaarheid der besproken factoren

Nadat eerst in dit opstel is ingegaan op de verklaring van het verschijnsel van de menselijke weerstand tegen verandering, en daarna de invloed van de persoonlijkheidsstructuur kort kon worden belicht, zijn in de voorgaande paragrafen enige van de belangrijkste factoren besproken, die ieder afzonderlijk een zekere invloed hebben op de feitelijke mate van weerstand tegen veranderingen. Thans zal moeten worden nagegaan welke van deze factoren

41) Acker (1966).

42) Kosiol (1959).

43) Dale (1962).

44) Dale (1962), vooral blz. 240-242.

ma $b$ blz. 216 
door de leiding van de onderneming te beïnvloeden zijn, binnen het streven naar een op marginalisering van veranderingsprocessen gerichte strategie, welke laatste een plaats vindt in het kader van het streven naar flexibele organisaties. Wij zullen derhalve moeten bezien òf, en in hoeverre de eerder besproken factoren beïnvloedbaar zijn, en daarbij met name ook moeten nagaan op welke termijn de factoren door de leiding kunnen worden beïnvloed. Vanuit deze vraagstelling bezien wij thans de eerder besproken factoren wederom afzonderlijk.

\section{De eigen inhoud van de verandering}

Bij de bespreking van de factor ,eigen inhoud" kan ervan worden uitgegaan, dat er doorgaans, ook bij het oplossen van organisatorische vraagstukken, vele wegen zijn die naar Rome leiden. Een bepaald probleem kan in het algemeen op een aantal alternatieve wijzen worden opgelost; zij het dat dan die oplossingen van elkaar verschillen doordat zij verschillende ,neveneffecten" hebben, en daardoor in feite strikt genomen niet ",hetzelfde probleem in dezelfde mate oplossen". Bij het kiezen uit de alternatieven, die ondanks verschillen in neveneffecten, het kernprobleem naar tevredenheid kunnen elimineren, kan de leiding zich nu mede laten leiden door de overweging dat alternatief te kiezen, dat de geringste penetratiediepte heeft, en daarmee als zodanig bijdraagt tot marginalisering van het veranderingsproces. Wij moeten constateren, dat de leiding t.a.v. de keuze van de eigen inhoud van de verandering, in het algemeen op korte termijn wel enige speelruimte heeft. Soms zal die speelruimte niet groot zijn, of zullen de mogelijke alternatieven elkaar uit een oogpunt van penetratiegraad niet veel ontlopen; niettemin kan minstens met de hier bedoelde overweging rekening worden gehouden daar waar uit alternatieven kan worden gekozen.

\section{Persoonlijke omstandigheden van de betrokkenen}

De factor ,"persoonlijke omstandigheden" zal door de leiding van de onderneming op korte termijn vrijwel niet kunnen worden beïnvloed. Op langere termijn evenwel moet ook de beïnvloeding van de stand van de hier bedoelde variabelen als: leeftijd, sexe, burgerlijke staat, en economische zekerheid, zeer wel tot de mogelijkheden worden gerekend. Een gericht personeelsbeleid immers, zal, op langere termijn, die voorwaarden kunnen scheppen, die op zich kunnen bijdragen tot marginalisering van de veranderingsprocessen in de organisatie van een onderneming. Zeer wel kan door middel van selectie, beloning, en promotiebeleid worden bijgedragen tot het creëren van zodanige persoonlijke omstandigheden der leden van de organisatie, dat vanuit deze hoek de weerstand tegen verandering kan worden beïnvloed. Ook via het vestigingsplaatsbeleid zijn te dezen beïnvloedingen denkbaar, zij het dat uiteraard daarbij - zoals ook binnen het personeelsbeleid het geval zal moeten zijn - niet alléén de gevolgen voor de flexibiliteit van de organisatie een rol spelen.

\section{Voorbereiding en introduktie}

Met betrekking tot de factor ,voorbereiding en introduktie” kunnen wij kort 
zijn. Het valt gemakkelijk in te zien, dat de wijze waarop de veranderingen worden voorbereid en worden geintroduceerd, in sterke mate door de leiding kan worden bepaald. Dit marginaliserend instrument is wel bij uitstek door de leiding te beïnvloeden, al moet hierbij worden opgemerkt, dat de mogelijkheid op korte termijn veranderingen aan te brengen in de wijze waarop de leiding gewend is de veranderingen voor te bereiden en te introduceren, niet moeten worden overschat. Wij komen hierop later nog terug.

\section{Vertrouwen}

Het behoeft weinig toelichting, dat de vertrouwensrelatie tussen leiding en uitvoering in een organisatie, door de leiding niet anders dan op lange termijn kan worden ontwikkeld. Vertrouwen is iets dat groeit, en bovendien langzaam groeit. Naast hetgeen hierom trent eerder reeds werd opgemerkt, waarbij vooral te denken is aan het labiele karakter van de vertrouwensrelatie, valt bovendien te bedenken, dat de samenstelling van de leden van de organisatie doorgaans veranderlijk is, en ook dit verschijnsel noopt tot gedurige aandacht voor het ontwikkelen en koesteren der vertrouwensrelaties.

\section{Duur van de veranderingsloze periode}

De duur van de aan de verandering voorafgaande veranderingsloze periode kan door de leiding van de onderneming op tal van wijzen worden beinvloed, doorgaans op betrekkelijk korte termijn. Niet alleen stelsels van job-rotation bieden op dit punt mogelijkheden, men kan ook denken aan systemen van job-enlargement, die immers op zich ook al meer afwisseling en verandering in het werk brengen. Meer in het algemeen kan de leiding streven naar het aankweken van een dynamische mentaliteit, onder meer door een klimaat te creëren, waarin verandering geleidelijk als vanzelfsprekend wordt beschouwd. In concreto valt hier onder meer te denken aan de toepassing van het systeem der interne promotie, het creëren van tijdelijke werkverbanden als projectgroepen, detachering en dergelijke. Ook het „up to date" houden van processen, methoden, zelfs van werkruimten en inventaris kan een bijdrage leveren tot gewenning aan verandering, en daarmee tot marginalisering van volgende veranderingen.

\section{Bewijsbaarheid van de verbetering}

In aansluiting bij hetgeen m.b.t. de thans te bespreken factor eerder werd opgemerkt, kan worden opgemerkt, dat in het algemeen langs tweeërlei wegen de factor „bewijsbaarheid van de verbetering" kan worden beïnvloed. In de eerste plaats kon reeds worden vastgesteld, dat maatregelen die het organisatorisch provincialisme tegengaan bijdragen tot een perceptie van verandering als verbetering, zonder dat daarbij noodzakelijkerwijs ook de eigen situatie verbetert. Vooral door de vertegenwoordigers van de richting van "Organization Development" zijn te dezen technieken ontwikkeld, waarop binnen het bestek van dit opstel onmogelijk kan worden ingegaan, en waarnaar wij - hoewel wij hierop zijdelings nog terugkomen - de lezer moeten verwijzen. Op deze plaats in ons betoog zij volstaan met de opmerking, dat de effecten van de „Organization Development”, zoals ook later nog zal 
worden uitgewerkt, doorgaans, op korte termijn verwaarloosbaar zijn.

Niet alleen door het organisatorisch provincialisme in de organisatie te verminderen is de bewijsbaarheid van de wenselijkheid van bepaalde veranderingen te vergroten; ook betere fundering van de instrumentele organisatietheorie kan daartoe - middels objectivering van de voorspellingen - bijdragen. Daartoe zullen evenwel modellen dienen te worden ontwikkeld, en zal de kennis van de causale relaties binnen ingewikkelde dynamische en open systemen als organisaties zijn, belangrijk moeten worden uitgebouwd. Wanneer men ziet hoever de systeem theorie inmiddels gevorderd is, of liever: hoe weinig ver zij inmiddels gevorderd is, valt te verwachten dat te dezen op korte termijn geen bijzondere resultaten mogen worden verwach $t^{45}$ ). Overigens staan wij bij deze tweede manier om de bewijsbaarheid van verbeteringen te vergroten niet langer stil, omdat de leiding van de onderneming hier een betrekkelijk ondergeschikte rol bij zal spelen.

Wanneer wij nu het voorgaande deel van de beschouwing in deze paragraaf samenvatten, kan worden vastgesteld, dat in beginsel alle eerder besproken factoren, die op zich van invloed kunnen zijn op de feitelijke mate van weerstand tegen verandering, door de leiding van de onderneming te beïnvloeden zijn, zij het dat sommige daarvan niet anders dan op langere termijn beïnvloed kunnen worden.

\section{Het combineren van marginaliserende maatregelen}

Vooral een drietal omstandigheden pleiten ervoor, in het algemeen in ondernemingen een combinatie van veranderingsmarginaliserende maatregelen aan te bevelen. In de eerste plaats mag worden verondersteld, dat het gecombineerde effect van een pakket van maatregelen doorgaans zekere synergische effecten zal opleveren, in die zin, dat het effect van de combinatie groter is dan het totaal van de afzonderlijke effecten.

In de tweede plaats pleit voor een combinatie van maatregelen, de omstandigheid, dat niet altijd duidelijk is welke marginaliserende factor onder bepaalde verhoudingen de meest werkzame zal zijn. De onzekerheid die hieruit voortvloeit, en waarop onder meer door Touraine ${ }^{46}$ ) gewezen wordt, maakt in het algemeen een combinatie aantrekkelijk, omdat ten minste daarmee de waarschijnlijkheid kan worden gemaximaliseerd, dat de meest bepalende factor ook inderdaad in het beleidspakket vertegenwoordigd is. Een derde factor die voor combinatie pleit, hangt samen met het verschijnsel, dat de onderlinge verhouding der effectiviteitsgraden van de afzonderlijke veranderings-marginaliserende factoren in de tijd geenszins constant behoeft te zijn. ${ }^{4}$ ) Negatief geformuleerd kan de wenselijkheid van de toepassing van een pakket van maatregelen derhalve zo worden omschreven: zonder combinatie verliest men de voordelen der synergie, terwijl tevens het risico belang-

45) De relatief nog steeds betrekkelijk grote mate van ontevredenheid over het werk van externe organisatieadviseurs (vgl. hiervoor Willems (1972)), valt wellicht minstens ten dele te verklaren uit de gebrekkigheid die vooralsnog de organisatietheorie kenmerkt.

46) Touraine (1965) (b), blz. 99.

47) Touraine (1965) (b), blz. 98. 
rijk kan toenemen, dat de meest bepalende factor niet in het pakket vertegenwoordigd is. Indien dan voor combinatie moet worden gepleit, volgt hieruit tevens de noodzaak van een lange termijn oriëntatie, zoals thans afzonderlijk zal worden bezien.

\section{De betekenis en noodzakelijkheid van een lange termijn beleid}

In het voorgaande deel van dit opstel is enerzijds naar voren gekomen, dat een aantal van de marginaliserende variabelen niet anders dan op lange termijn kunnen worden beïnvloed, terwijl anderzijds kon worden aannemelijk gemaakt, dat in het algemeen een combinatie van maatregelen moet worden aanbevolen. Wanneer wij deze beide elementen combineren, volgt daaruit, dat een strategie gericht op de flexibilisering van de organisatie, door middel van de marginalisering van veranderingsprocessen, noodzakelijk op een lange termijn visie zal dienen te berusten. Niet alleen een factor als het vertrou$w^{2} n^{4}$ ) kan alleen op lange termijn worden ontwikkeld, hetzelfde geldt t.a.v. - wat men wel noemt - de organisatie-culturele factoren, die door de „Organization Developers" zo sterk op de voorgrond worden gesteld als voorwaarden voor het goed functioneren van een organisatie, en het aanpassingsvermogen ervan. Bennis bijvoorbeeld wijst uitdrukkelijk op de lange termijn oriëntatie die vereist is voor het ontwikkelen van de organisatiecultuur, door middel van wat hij noemt een ,complex educational strategy" ${ }^{9}$ ). Lawrence en Lorsch wijzen er eveneens op dat het ontwikkelen van organisatie-culturele variabelen in hoge mate tijdrovend is, en de facto continu de aandacht vergt. ${ }^{50}$ ). Voor eenzelfde opvatting kan worden verwezen naar Burke en Schmidt ${ }^{51}$ ), terwijl ook French en Bell als een van de elementen van Organization Development, in hun omschrijving daarvan opnemen: ,, it is a long range effort" ${ }^{2}$ ).

In het kader van ons betoog - waarin op de werkwijze der Organization Developers onmogelijk kan worden ingegaan - moet vooral worden bedacht, dat het juist de door de Organization Developers bedoelde organisatie-culturele factoren zijn, zoals: openheid, mate van vertrouwen en respect, en bereidheid tot reële samenwerking, die zullen bepalen of, en in hoeverre, de leiding van de onderneming bereid zal zijn de door ons genoemde veranderings-marginaliserende factoren, in positieve zin te beïnvloeden. Het valt nu gemakkelijk in te zien dat het beleid gericht op marginalisering van veranderingsprocessen, in het kader van de flexibilisering van de organisatie der onderneming, slechts een kans van slagen zal hebben, indien de topleiding de beleidselementen ondersteunt ${ }^{53}$ ), en bereid is in deze richting, zowel in termen van tijd als in termen van geld, de nodige investeringen te doen.

48) Het is opvallend hoe belangrijk de plaats is die deze factor inneemt in McGregor's „teamdevelopment-scale". Vgl. McGregor (1967), blz. 172 e.v.

49) Bennis (1969), blz. 2.

50) Lawrence en Lorsch (1969).

51) Burke en Schmidt (1972).

52) French en Bell (1973), blz. 15.

53) Men vindt dit denkbeeld onder meer ook onderstreept bij Bennis (1969) en Lawrence en Lorsch (1969).

$m a b$ blz. 220 
Zonder lange termijn oriëntatie is het hier bedoelde streven naar onze overtuiging gedoemd te mislukken.

\section{Positieve theorie en instrumentele aanbevelingen}

Indien nu in het voorgaandy kon worden afgeleid, dat de leiding van de onderneming, wier organisatie over de nodige flexibiliteit moet beschikken, er in het algemeen goed aan zal doen een veranderingsmarginaliserende strategie te voeren, waarbij tal van maatregelen in de sector van het personeelsbeleid een rol van betekenis spelen, is het gewenst het instrumentele karakter van deze uitspraak te onderstrepen.

Het valt gemakkelijk in te zien, dat de maatregelen, waartoe het bedoelde beleid zal voeren, en zoals die in het voorgaande zijn geschetst, in het algemeen voor de betrokken werknemers een verbetering van het werkklimaat kunnen betekenen. Benadrukt moet evenwel worden, dat in het kader van de onderhavige analyse, aan de bedoelde aanbevelingen niet zozeer ,,autonome sociale waarden" ten grondslag liggen, zoals deze bijvoorbeeld door Van Zuthem ${ }^{54}$ ) worden gehanteerd.

De aanbevelingen, zoals: goede beloning, afwisselend werk, participatief leiderschap en dergelijke, zijn in het voorgaande niet gedaan omdat dit opzichzelf positieve sociale waarden zouden kunnen worden geacht, maar zijn gedaan, omdat bepaalde positief theoretische verbanden konden worden aangenomen tussen: enerzijds de stand van deze variabelen, en de mate van weerstand tegen veranderingen anderzijds. Anders dan bij Van Zuthem het geval is, wiens beschouwingen over het personeelsbeleid in feite normatieve uitspraken insluiten ${ }^{\mathbf{5}}$ ), en anders ook dan men bijvoorbeeld bij Bennis wel kan aantreffen ${ }^{56}$ ), dragen de door ons geformuleerde aanbevelingen - in de terminologie van Machlup ${ }^{5}$ ) - een zuiver instrumenteel karakter. Het verschil met de normatieve benadering vanuit de onderkenning van bepaalde sociale waarden, ligt nu vooral hierin, dat de aanbevelingen zoals door ons binnen het kader van dit opstel geformuleerd, gezien het instrumentele karakter van de analyse, conditioneel van aard zijn. Op basis van een waardevrije analyse kan het bedoelde beleid slechts onder omstandigheden worden aanbevolen, welke thans nader zullen worden geformuleerd, in enige relativerende slotopmerkingen.

\section{Afsluitende opmerkingen}

Zoals terloops in de inleiding bij dit opstel reeds werd opgemerkt, moet worden beklemtoond, dat de flexibiliteit van de organisatie van onderne-

54) vgl. Van Zuthem (1967).

55) Bij Van Zuthem immers staat een maatschappijcritisch oordeel over de wenselijkheid van bepaalde maatregelen voorop. Zie voor de doorwerking van deze gedachten bijvoorbeeld de N.K.V.-Brochure „Vakbeweging en Personeelsbeleid”, waarin juist de uitgangspunten van Van Zuthem een centrale plaats innemen.

56) Bedoeld wordt hier de passage in Bennis, waarin wordt geschreven, dat „Organization Development" in wezen gericht is op het ontwikkelen van meer democratische ondernemingen. Vgl. Bennis (1969), blz. 35.

57) vgl. Machlup (1969), blz. 100-106.

$m a b$ blz. 221 
mingen niet alléén door de mate van menselijke weerstand tegen veranderingen wordt bepaald. Onder meer door Ansoff en Brandenburg ${ }^{5}$ ) is benadrukt, dat te dezen ook invloeden uitgaan van de organisatiestructuur, en in het bijzonder van het model van organieke verbijzondering.

Naast de structuur van de organisatie, op het niveau der afdelingen, kunnen bovendien de soort der gehanteerde procedures van grote invloed zijn op de flexibiliteit van de organisatie als geheel, zoals bijvoorbeeld door Mey terzake van de budget-procedure is opgemerkt. ${ }^{59}$ ) Eveneens kan tot de flexibiliteit van de organisatie als geheel worden bijgedragen door de flexibiliteit van de daarin aanwezige elementaire bestanddelen, als: machines en gebouwen. ${ }^{60}$ ) Deze opsomming is nog geenszins volledig. Wel komt daaruit naar voren, dat het marginaliseren van veranderingsprocessen moet worden beschouwd als één der mogelijke middelen ter flexibilisering van de organisatie als geheel. ${ }^{61}$ )

Ook in een tweede opzicht is enige relativering van de eerdere aanbevelingen gewenst. De vermindering van weerstanden tegen verandering immers, werd door ons behandeld als middel tot flexibilisering van de interne organisatie. Het is daarom gewenst, te onderstrepen, dat niet voor iedere onderneming de flexibiliteit als zodanig een even belangrijk aspect van de kwaliteit van de organisatie behoeft te worden geacht, terwijl tevens voor eenzelfde onderneming de relatieve betekenis van het flexibiliteitscriterium in de tijd kan verschillen. Ondernemingen die in een betrekkelijk stabiele omgeving functioneren, zullen veelal bij uitstek streven naar efficiency van de interne organisatie, en aan de flexibiliteit minder gewicht behoeven toe te kennen. Hetzelfde kan het geval zijn voor ondernemingen, die slechts voor een bepaalde duur zijn opgericht, en zich daarom niet zullen hoeven aanpassen aan veranderingen op langere termijn.

Intussen moet hierbij worden opgemerkt, dat de laatstbedoelde relativering, welke in het kader van een instrumentele analyse theoretisch noodzakelijk is, praktisch gesproken van weinig gewicht zal zijn. In de eerste plaats zijn de verhoudingen waaronder ondernemingen functioneren in het huidige tijdsbestek in het algemeen overwegend dynamisch te noemen, zowel in economisch, alsook in technologisch en maatschappelijk opzicht. Praktisch gesproken is derhalve wat dit betreft de flexibiliteit van de interne organisatie voor een zeer groot deel der ondernemingen in het algemeen als een belangrijk aspect van de kwaliteit te beschouwen.

In de tweede plaats moet worden vastgesteld, dat in het algemeen slechts een zeer bescheiden fractie van het aantal ondernemingen, bij voorbaat voor een beperkte duur wordt opgericht. Het continuïteitsstreven staat bij ondernemingen doorgaans voorop. ${ }^{62}$ ) Niet alleen de economische theorie werkt

58) vgl. Ansoff en Brandenburg (1969).

59) Mey (1951); vgl. bv. ook Van der Schroeff (1968).

60) vgl. voor een interessante beschouwing bv. Meffert (1969).

61) vgl. voor een beschouwing over de onderlinge verbondenheid van deze middelen bijvoorbeeld Leavitt (1970). Zie bovendien vrijwel ieder boek over de systeembenadering van het organisatieprobleem.

62) Bedoeld is hier de orgaancontinuiteit en niet de functiecontinuiteit. Vgl. voor dit onderscheid Van Philips (1962), blz. 7-8.

$m a b$ blz. 222 
alom met deze premisse ${ }^{63}$ ), ook ondernemers zelf onderstrepen de betekenis van de continuïteit veelal expliciet. ${ }^{64}$ ) Zo kan worden afgesloten met de opmerking, dat een aantal maatregelen op het gebied van het personeelsbeleid, die soms worden anbevolen op basis van een normatief oordeel omtrent hetgeen sociaal wenselijk zou zijn - en die overigens ook door ons op die basis aanbevelenswaardig worden geacht - eveneens een aanbevelingsbasis kunnen vinden in een strikt instrumentele analyse, waarin van de premisse van het continuïteitsstreven wordt uitgegaan, en waarin daarmee de flexibiliteit van de organisatie als een actueel kwaliteitscriterium wordt beschouwd.

\section{Bibliografie}

(waarin kortheidshalve geen informatie over vertaling, uitgever en druk vermeld)

Acker, H. B., Organisatieanalyse. Alphen aan den Rijn, 1966.

Ansoff, I. en Brandenburg, R., A Language for Organization Design. In: E. Jantsch (ed): Perspectives of Planning. Parijs, 1969.

Argyris, Ch., Mens en Organisatie in het bedrijf. Antwerpen, 1964.

Barnes, L. B., Organizational change and field experiment methods. In: V. H. Vroom (ed): Methods of Organizational Research. Pittsburgh, 1968.

Beckhard, R., Organization Development: Strategies and models. Reading (Mass.), 1969.

Bennis, W. G., Changing Organizations. New York, 1966.

Bennis, W. G., Organization Development; its nature, origin and prospects. Reading (Mass.), 1969.

Berg, J. H. van den, Metabletica. Nijkerk, 1965.

Bergson, H., L'évolution créatrice. Parijs, 1962.

Blake, R. R. en Mouton, J. S., Corporate excellence diagnosis. Austin, Texas, 1968.

Blake, R. R. en Mouton, J. S., Building a dynamic corporation through grid organization development. Reading (Mass.), 1969.

Bosboom, P. H., Rede, 3e Heidepark Conferentie van de Orde voor Organisatie-Adviseurs. 1964 (niet in de handel).

Burke, W. W. en Schmidt, W. H., Management en Organisatieontwikkeling. In: Synopsis, mrt/apr., 1972.

Coch, L. en French, J. R. P. jr., Overcoming resistance to change. In: Human Relations, $1948,1$.

Coltof, H., Veranderen en aampassen in de organisatie van het bedrijf. Alphen aan den Rijn, 1965.

Dale, E., Planning and developing the company organization structure. New York, 1962.

Davey, N. G., The consultants role in organizational change. In: NSU-Business Topics, 1971, 2.

Dean, J., The management counsel profession. Bloomington (Ins.), 1940.

DerKinderen, F., Hoofdlijnen van de Bedrijfsstrategie. Amsterdam, 1966.

Drucker, P., The practice of management. New York, 1954.

Edelman Bosch, J. B. M., Bijdrage (blz. 267-276) in: Encyclopedie van de Bedrijfseconomie. Bussum, 1971.

French, W. L. en Bell, C. H. jr., Organization development; behavioral science intervention for organization improvement. Englewood Cliffs, N.J., 1973.

Fromm, E., De gezonde samenleving. Utrecht, 1971.

Goldschmidt, O., De doeleinden van de onderneming. Leiden, 1966.

Gouldner, W. A., A study of an unofficial strike. Londen, 1955.

Hardwick, C. T. en Landuyt, B. F., Administrative strategy and decision making. Cincinnati (Ohio), 1966.

Idenburg, Ph. A., Het gezag in de onderneming. Leiden, 1966.

Johnson, R. A., Kast, F. E. en Rozenzweig, J. E., The theory and management of systems. New York, 1967.

Judson, A. S., A manager's guide to making changes. Londen, 1966.

Kosiol, E., Grundlagen und methoden der Organisationsforschung. Berlijn, 1959.

Krüger, G., Fundamentele problemen der hedendaagse wijsbegeerte. Antwerpen, 1962.

63) vgl. bv. Goldschmidt (1966), Van der Schroeff (1968) en DerKinderen (1966).

64) Verwezen zij hiervoor naar verscheidene sociale statuten van ondernemingen. Zie ook Tromp (1966), blz. 501 . 
Kuyken, D., Een visie op de organisatie-adviseur. In: Organiseren-organisatiekunde, Alphen aan den Rijn, 1966.

Lawrence, P. R. en Lorsch, J. W., Developing Organizations, diagnosis and action. Reading (Mass.), 1969.

Leavitt, H. J., Applied organizational change in industry: structurel, technical and human approaches. In: V.H. Vroom en E. L. Deci (eds.): Management and motivation. Harmondsworth, 1970.

Lewin, K., Frontiers in group dynamics. In: Human Relations, 1947, 1.

Likert, R., The human organization: its management and value. New York, 1967.

Lippitt, R., Watson, J. en Westley, B., The dynamics of planned change. New York, 1958.

Machlup, F., Positive and normative economics. In: R. L. Heilbroner (ed): Economic means and social ends; Englewood Cliffs, N.J., 1969.

Meffert, H., Zur Problem der Betriebswirtschaftlichen Flexibilität. In: Zeitschrift für Betriebswirtschaftlehre, 1969, 12.

Malotaux, P. Ch. A., Algemene inleiding in het kader van ,voordrachten over flexibiliteit en efficiency". In: De Ingenieur, 1966, blz. A-497 - A-500.

McGregor, D., The human side of enterprise. New York, 1960.

McGregor, D., The professional manager. New York, 1967.

Mey, A., Flexibele en variabele budgettering. 9e Congres de l'organisation scientifique, Brussel, 1951.

Nederlands Katholiek Vakverbond, Vakbeweging en personeelsbeleid. Utrecht, 1974.

Newman, W. H., Summer, Ch. E. en Warren, E. K., The process of management. Englewood Cliffs, N.J., 1972.

Oldendorff, A. en Daniels, M. J. M., Sociologie en Psychologie. Collegedictaat T.H. Eindhoven (niet in de handel), 1965.

Peursen, C. A. van, Strategie van de cultuur. Amsterdam, 1970.

Philips, P. A. M. van, Aspecten van het continu itteitsbegrip in de economische analyse. Haarlem, 1962.

Rubinstein, M., Werken met groepen in organisatieadviesprojecten. In: Maandblad voor Accountancy en Bedrijfshuishoudkunde, 1971, blz. 206-223.

Schroeff, H. J. van der, Leiding en organisatie van het bedrijf. Amsterdam, 1968.

Seiler, J. A., Systems analysis in organizational behavior. Homewood, Ill., 1970.

Tannenbaum, R., Weschler, I. R. en Massarik, F., Leadership and organization: a behavioral science approach. New York, 1961.

Touraine, A., Workers attitudes to technical change. Parijs, 1965 (a).

Touraine, A., Acceptance and resistance. Parijs, 1965 (b).

Tromp, Th. P., De ondernemersvisie op flexibiliteit en efficiency. In: De Ingenieur, 1966, blz. 501 e.v. Verburg, P., Organiseren en Organisatieonderzoek. Leiden, 1966.

Wattel, A., Organisatieplanning als instrument voor de ondernemingsplanning. In: Maandblad voor Accountancy en Bedrijfshuishoud kunde, 1968, blz. 485-497.

Willems, J. G. L. M., Bent U tevreden over Uw adviseur? ; twee peilingen naar het oordeel van clienten. In: Tijdschrift voor effectief directiebeleid, 1972, 11.

Willems, J. G. L. M., De raadselachtige populariteit van Douglas McGregor. In: Intermediair, 1974, 34.

Willener, A., The worker and the organizational system. In: A. Touraine (ed): Workers attitudes to technical change. Parijs, 1965.

Zuthem, H. J. van, Arbeid en arbeidsbeleid in de onderneming. Assen, 1967. 